\title{
An Experiment in Integrated Library Service
}

Dr. Orne is director, Air University Library, Maxwell Air Force Base, Ala.

$\mathrm{F}^{\mathrm{OR}}$ DECADEs academic libraries have - struggled with the problem of bringing their public and the library's collections closer together. That this is true is evident in large measure in the literature of librarianship where many and diverse means of improving this situation have been described at length. The problem of bringing together the user and library materials became acute in the Air University four years ago. Shortly thereafter an experiment was initiated and the experience of the past three years is here reported for such use as it may be in other academic communities.

\section{The Library's Publics}

When reduced to its fundamental bases, the library public of an academic community should properly be characterized in three types. The first of these, and probably the largest group, includes all those who use the library as a place to read and study, in brief, as a study hall. This part of our public is primarily concerned with comfortable seats, a reasonably quiet room, and with library materials only, as assigned readings or books, near at hand. If this group has a problem, it is purely physical and not our concern here.

The remaining two groups are concerned with what is loosely called research and we do find the basis of our problem with them.

The research publics of an academic library are of two quite distinct types. One of these types, representing a relatively small proportion of the whole, includes the typical fully-trained faculty member, possessing his Ph.D., having extensive experience in research methods, actively engaged in productive research, fully acquainted with the current bibliography of his field, and thoroughly aware of the resources he can expect to find in the research academic library. Obviously, a member of this select group is a paragon, and his numbers are few in any academic community.

The second of the research publics stands upon the middle ground. It includes advanced students and new young instructors in massive numbers. Also included is a type of professor we all know, venerable in service, fixed in bibliography, and neolithic in course content. These people are relatively unacquainted or out of touch with the literature of their respective fields. By numbers and potential, they are the most difficult, yet most rewarding, of the academic library's public.

Our statistics of libraries, as collected today, do not reveal the separation of these three kinds of use; however, a realistic library administrator will readily recognize this grouping, for he must deal with it in every working day on his job. Our problem, and the area in which we have experimented, concerns particularly the latter group, not the reading-room user or the active professional researcher. The problem is one of access. How can these users be reached? How can library materials be made known to them, and how can they be brought into continuous and ready employment of the materials they should have? 


\section{EARLY EXPERIMENTS}

It is probably not necessary to prove that such a problem exists; however, it may be useful to indicate some of the earlier attempts to satisfy some of the above questions. Without going back too far, librarians remember well the experiment at Stephens College, introduced by B. Lamar Johnson, ${ }^{1}$ aimed in the general direction of taking the library to the students and the faculty. Somewhat later, Harvie Branscomb stressed the importance of coordinating teaching and using the library to good effect. $^{2}$ Guy R. Lyle sums up these efforts succinctly and to the point:

an increased emphasis is being placed on the coordination of faculty and library effort in the common goal of instruction. Dr. B. Lamar Johnson, dean and librarian of Stephens College and Dr. Harvie Branscomb of Vanderbilt University have made this the major thesis of three important books which have provoked thought and discussion in library and faculty groups throughout the country. Few disagree with their basic premise, though a good many librarians are confused and skeptical regarding the methods proposed for accomplishing this closer coordination in a common good. ${ }^{3}$

Physcial approaches to the problem have not been lacking. An early one was the development of divisional reading rooms at Colorado, Nebraska, and in many smaller libraries. ${ }^{4}$ This plan was designed to bring more materials in a given field closer to the reading-room public. It may have improved the usefulness of the reading rooms, but it cannot be said to have succeeded in reaching our problem public. A recent de-

\footnotetext{
1 B. Lamar Johnson, Vitalizing a College Library (Chicago: ALA, 1939).

2 Harvie Branscomb, Teaching with Books (Chicago: ALA, I 940).

${ }_{3}$ Guy R. Lyle, The Administration of the College Library (2d ed.; N.Y.: Wilson, 1949), p. I97.

4 R. E. Ellsworth, "Colorado University's Divisional Reading Room Plan." COLLEGE AND RESEARCH LIBRARIES, II (March, I941), I03-9, I92.
}

velopment is that of the undergraduate library or reading room. This concept has reached its fullest flowering with the undergraduate library at Harvard. ${ }^{5}$ This idea is now a part of the planning of many new library buildings.

Each of the above briefly noted experiments or concepts had specific goals. Each in its own way contributed something to the improvement of library services with one public or another. Each represents a clear evidence that many thoughtful men have been greatly concerned over the seeming lack of coordination between the user and the library. As we see it, none of these ideas has solved the problem of the intermediate public, the one public which, in our eyes, gives serious proportions to the stature of the library in an academic community.

\section{The Specific Problem of the Air Uni- VERSITY LIBRARY}

Perhaps the principal reason why the Air University has been so aware of the kind of problem it has, is that in many ways the problems of a library serving an academic institution in a military community under both government and military regulations are certain to be somewhat aggravated by these conditions. ${ }^{6}$ What might be a matter of concern in a typical academic institution or what might even pass unnoticed becomes a matter of very critical concern requiring immediate and drastic action to avoid completed dissolution in a library like ours.

The first difficulty for the Air University Library lies in the character of its collections and its areas of interest. Most academic libraries have books, journals, and government documents in considerable numbers. Our library has all of these, but

\footnotetext{
5 K. D. Metcalf, "The Lamont Library; II. Function." Harvard Library Bulletin, III (Winter, 1949), $12 \cdot 30$.

"Jerrold Orne, "The Major Problems of Military Libraries." Special Libraries, XLIV (September, I953), 268-7I.
} 
superimposed is a working collection of over half a million classified reports and documents. Further, by the nature of our fields of interest, these reports and documents are our primary materials, where in other libraries such material is secondary or not even present. To compound the difficulty, their subject content and format is not such that it lends itself easily to analysis or use. In the air age and in an institution devoted to the preparation for command of Air Force officers, in subject fields where no librarian initially possesses the basic subject competence, this library begins its work in most cases beyond the point where other libraries have exhausted their resources.

In most academic institutions the typical student body is a selected one, composed of men and women in a continuing program of education, i.e., students. In the Air University, "students" have this name only by virtue of their presence for the short period of a year or less in the Air University. Typical students are senior officers of the Air Force with from five to fifteen years away from any academic experience, frequently not interested in an academic experience but preferring their chosen field of operations and, though necessarily concerned with succeeding in their course work, not at all interested in the cloistered walls or contents of a library. These students frequently cannot remember when last they saw the inside of a library. They understand very little of its purpose or methods. There is no compulsion on the student to use the library, and we might reasonably expect to see not more than one in ten of these students within our walls. Further, our students are not of typical student age. Most students of the $\mathrm{Air}$ University are mature senior officers with family responsibilities, well advanced in their profession. The assignment to a course of study at the University is for some an unsought and unappreciated duty.
This institution differs from the norm also in the character of its faculty and, to a certain degree, its administrative staff. Although there are a considerable number of civilian educators, advisors, and lecturers, the teaching staff and course planning staff are largely made up of military officers who do not differ greatly from their students. Almost the only difference in most cases is the fact that the instructor has been through the course, and has been assigned an extended tour of duty at the Air University because of demonstrated abilities. Again, the duty of the instructor is very frequently an assignment neither sought nor desired. The instructor has very little more experience with library method and materials than the student. Further, by the nature of their professional field of work, these instructors do not keep up with their field through literature but rather through the application of the tools developed for them by others. They are wholly unlike a typical university professor in that their literature is not publicized through catalogs, reviewing journals and publishers' announcements which come almost automatically to their desk. What literature does exist for them not only does not commonly reach their desks, but must be diligently pursued, and may be found only after considerable effort. Obviously, the Air University instructor or planning staff member cannot be considered independently library or research minded.

\section{Plan for the Experiment}

It is clear from the above paragraphs that the Air University Library had a problem which demanded some new approach. A plan to meet the need was devised in I95I. It evolved out of the reorganization of staff and functions within the library, the backbone of which was a reversal of direction in employment of staff. In I95 I the majority of the library staff were engaged in what 
could be properly called technical processes activities with a much smaller number concerned with activities directly involved in serving the library's public. In a few years it has been possible to relocate and orient the staff so that at the present time a considerable majority of staff members are engaged in public service activities. Within the public service activities, the first step was to separate what we call general reference work and the work of a now large group of well-qualified librarians who are called bibliographic assistants.

The small general reference group is responsible for manning a reference desk (which is the first point of access to the user) throughout the long scheduled hours. In so far as their reference work is concerned, these librarians are beginning reference librarians who are qualified and able to answer any of the typical fact questions, and who know specifically the particular competences of each of the bibliographic assistants so as to be able to direct any patron who needs more advanced guidance to the right person. The librarians in general reference are in training for advancement to the bibliographic assistant level.

The bibliographic assistants are given course or subject assignments within fairly narrow limits. Each one has the responsibility for the most complete knowledge of all library resources on a given subject or in a given field. A bibliographic assistant is freed of desk scheduled assignments from 50 to 90 per cent of his time. These librarians are instructed to be away from the library and together with their constituents, the students, faculty and staff. Within their particular competences they spend as much time as necessary maintaining a continuous awareness of what is going on anywhere in the Air University that is their concern. These librarians may participate in every meeting of a course, or attend such lectures and classes as they will. They have free and direct communication with the instructors, the course planners, and administrative officers with whom they are concerned. Any bibliographic assistant who spends too much time in the library is looked upon with question. Under this concept these librarians are most useful when they are not in the library. It is this particular group, the bibliographic assistants, who represent the focal point of our experiment.

\section{Personnel}

It is not our belief that any librarian can qualify for the type of librarianship we look for from a bibliographic assistant. There are certain basic requirements. First, it is obvious that a bibliographic assistant must have an independence of mind and action sufficient to assure his success while working independently and in the field. Second, it is obvious that a person representing the library outside the library should be one with an outgoing and appealing personality. It goes without saying that a high order of intelligence is an imperative necessity for a librarian handling not only a difficult and uncommon field of information, but also working with a public uncommonly wellgrounded in its particular fields of operations. These are only some of the major requirements of a bibliographic assistant.

It may be interesting to note here that it has not been easy to bring the typical trained librarian into satisfactory operation within this concept of freedom of action. Beginning with personnel in place for obvious reasons, we very soon had a positive impression that a librarian without his own desk and without directed assignment may become very unhappy. It appears that our type of library training and operation in general has tended to create dependence to such a degree that when a staff member is added, he longs to be shown his desk and told when he will be at his desk. Without this, he may become very uncomfortable or 
ill at ease or feel a lack of direction. It was plainly quite a shock for some members of our staff to find that they had no desk and very little desk assignment. It took quite some time before they felt free to move. When acclimated to this concept, however, our best bibliographic assistants are impatient with desk assignments and feel most at home when they are working directly with their constitutents.

\section{Materials}

Discounting the need for desk assignment, there is a time and a place when the bibliographic assistant must be in the library. Obviously the librarian out in the field cannot be fully aware of what is passing through the library. The library receives hundreds of documents, periodicals, and books daily. Some means had to be found to assure that the bibliographic assistant would be fully informed about all of the useful materials entering the library daily which might serve to improve the work of its public. Thus, it was made a part of the daily routine of each bibliographic assistant to spend some time in the acquisitions section, reviewing books, journals, and documents as they entered the library, selecting and making notes of those which would serve them in some way. This provides a first-hand and immediate contact with a mass of material moving through the library. This is an approach from one side, i.e., the bibliographic assistant himself collects as much data as he can alone. We judge that this, although it is certainly good, may not be sufficient. Accordingly, we attacked the problem of information from the other direction: charging personnel in acquisitions, cataloging, and periodicals areas with informing any bibliographic assistant of materials which they notice in the course of their daily work that may be useful to each particular bibliographic assistant. The fields of work and subjects assigned to the bibliographic assistants are publicized to each person concerned so that all members of the staff who handle materials are continuously aware of the special fields of activity of each one of these super salesmen who go out to our world.

\section{Tools}

We have not given up the catalog, and the work of the catalogers supplements in detail all other informational efforts. In one field, periodicals, we have had to go one step further because of the nature of our fields of interest. Military journals are, in general, not indexed in commercial indexes. Accordingly, we produce and publish our own periodical index to military journals, ${ }^{7}$ by way of keeping the bibliographic assistants alive to even the smallest item in a periodical that may be useful in their work. Each bibliographic assistant is assigned from two to half a dozen military journals for indexing on a regular basis, these journals being chosen in the field of specialization of each bibliographic assistant. This indexing, though seemingly mechanical, takes relatively little time and frequently provides the bibliographic assistant with an article at his finger-tips which precisely fits a current need. As a by-product the $\mathrm{AU} \mathrm{Li-}$ brary provides to the entire military community an indexing tool not available from any other source.

\section{Physical Resources}

A final step in the plan for this experiment was to assure the accessibility and approachability of the place the users would know as the library. Like any other military installation, this library in its early years was set up in whatever quarters could be found, with whatever equipment was on hand, and with an understandably un-

${ }^{7}$ Air University Periodical Index ... Oct. I949-
Maxwell Air Force Base, Alabama, Air University,
1949- 
lettered idea of what a library can be in an academic community. That part of the library used for study and reading has been renovated completely to provide a bright, clean, well-furnished area with particular attention being given to establishing something approaching an academic study climate. Where previously those using the library appeared to regard it as an enlarged day room, present users recognize and accept the fact that this is the library, becoming aware of its special atmosphere as soon as they pass through its doors.

\section{Application}

The first contact the student has with the library is through an orientation lecture given by the bibliographic assistant assigned to his course. The lecture is followed immediately by a simple exercise which must be carried out in the library, calculated to introduce the student to the fundamental tools he will have to use during the school year. At the time of the orientation lecture the student is made aware of the assistance of this librarian assigned particularly to him. He will see this librarian regularly or intermittently in his classes and with his instructors. He frequently meets this person during class breaks and very soon comes to know where to go with any problem he may have. The librarian on the other hand is personally acquainted with a group of students and instructors and is continuously aware of what they are studying, what their requirements will be, and prepares to meet them in advance. By such close association and by participation in class discussions, the bibliographic assistant becomes increasingly able in his or her particular field of study. The incremental growth of this background knowledge over a period of years is considerable. With this first-hand learning is combined the librarian's own continuous searching of new materials, and when all this is supplemented by a continued supply of information concerning new materials by other members of the staff, the cumulative effect is overwhelming. The final result is that our bibliographic assistant gradually becomes a leading authority on the subjects assigned to him, and he is sought out increasingly by instructors and course planning personnel to aid in assuring the bibliographic currency of the course content. One ancillary benefit is obtained without effort through this kind of librarianship. The librarian participates in the activities of the group, acquires a sense of belonging, and his constituency begins to feel that he belongs to them. There is here a very useful step in the direction of breaking down the wall that frequently lies between librarian and patron. In our case, they do not live in different worlds; they are part of the same.

\section{Results}

After something more than three years of this experiment, we can now point to a number of valued gains for the library. We count as a most critical advance the redirection of the many library activities which have led to the majority of the staff being engaged in user-directed activities, rather than those of an archival or analytical type. Librarians everywhere deplore and bemoan the ever-increasing demands for technical processing personnel as the volume of production grows steadily in our country. We have other experiments in operation calculated to meet this problem. Suffice it to say that we have been able to redirect numbers of the staff to the field of bibilographic assistance while reducing the work load on our technical processes. We consider an important gain the fact that the library now participates in the educational process directly and continuously instead of serving in an ancillary fashion only as called upon. Stated simply, this means that the library is now in the field, selling 
its products in much the same manner as does any commercial manufacturer. Another gain lies in the character of library personnel and the general morale of the entire library staff which is due largely to the success of our salesmen. We now have a steadily increasing number of out-going personnel, independent thinkers who move freely and confidently to and from their work, as opposed to the former pedestrian, waiting, inward-turning group. We have personnel who know intimately and completely what we have to sell, engaged virtually full-time in selling the new, the useful, and the productive, achieving a freshness of materials beyond all common practice. From the point of view of the course director, the instructor and the student, this is a most happy situation. Our fields of endeavor require the freshness of last week's information to keep up with the air age. Through the bibliographic assistants and their continuous scrutiny of the working collections our courses have this currency. From the library's point of view, a great gain is made in the immediacy of use. This library is no archive. Materials which come in one day are in demand the next. There can be no prolonged delays in handling or availability. Everything moves to the point of use and the point of use is as sharp as our kind of human engineering can make it.

\section{CONCLUSIONS}

Obviously, any other kind of academic institution would have its own problems in carrying out the concept of bibliographic assistance. We have had unusual and greatly appreciated freedom to experiment in this field. The experiment in a sense was forced upon us, since without it plainly the library was failing. Regardless of what the experiment has done for us or what its application may be in other institutions, it does seem clear that academic libraries in the future must seek ways of promoting the use of their materials rather than counting heads in reading rooms if the profession of librarianship is to maintain its present high status.

\section{The Relation Between the Librarian and the College Administration}

\section{(Continued from page 352)}

in the curriculum, where the undergraduate often first becomes aware of the interrelationship of seemingly unrelated courses. Out of this common experience of four years may come one of the greatest values of higher education: its carry-over into life beyond the campus years, in the persistence of learning.

I cannot close without reference to the published papers of the nineteenth annual conference of the Graduate Library School of the University of Chicago appearing in the October, I954 issue of the Library Quarterly. Here, at length, from every angle, by distinguished authorities, the whole problem of "The Function of the Library in the Modern College" has been thoughtprovokingly explored. I have deliberately avoided specific reference to any single paper, stimulating as I found each of them, for these words of mine would have been at best an imperfect distillation. Nevertheless their papers have prompted and encouraged me in this survey of the implementation and integration of the college president's educational objectives as evidence of the relation between the librarian and the college administration. 